\title{
MAIN LEGAL ASPECTS OF THE HOUSEHOLD WASTE MANAGEMENT IN UKRAINE
}

\section{Kravchenko M. H.}

\section{INTRODUCTION}

The reformation of the household waste management sector in Ukraine is the logical step towards the adaptation of the Ukrainian legislation to the EU legislation in the field of waste and resources management. The necessity to bring the legislation of Ukraine in this sector in accord with the EU legislation is subject to the provisions of the Association Agreement between the European Union and its Member States, of the one part, and Ukraine, of the other part ${ }^{1}$, in particular the Annex $\mathrm{XXX}^{2}$ herein. This annex determines the list of EU legal instruments, the provisions of which should act as the landmarks which ensure the becoming of the household waste management in Ukraine as the European one. This refers to the provisions of the following EC directives: Directive 2008/98/EC of the European Parliament and of the Council of 19 November 2008 on waste and repealing certain Directives and the Council Directive № 1999/31/EC on the landfill waste, amended with the Regulation № $1882 / 2003 \mathrm{EC}^{3}$.

The specific steps on the reformation of the function of public administration of Ukraine on waste management as well as bringing this function into the conformity with the European standards are identified in the National strategy of waste management in Ukraine until the year $2030^{4}$. The provisions of this Strategy designed to achieve the specific goals; particularly, the following ideas should be practically implemented in Ukraine: the closed-loop economy, i.e. the economy oriented at the minimization of negative impact of the waste on the environment, non-waste production and reaching the goals of sustainable

\footnotetext{
${ }^{1}$ Угода про асоціацію між Україною, з однієї сторони, та Європейським Союзом, Європейським співтовариством з атомної енергії і їхніми державами-членами, з іншої сторони : Закон України від 16 вересня 2014 р. Офіиійний вісник Украӥни. 2014. № 75. Ст. 83.

2 Додаток XXX до Угоди про асоціацію між Україною, з однієї сторони, та Європейським Союзом, Свропейським Співтовариством з атомної енергії і їхніми державами-членами, з іншої сторони. URL: http://www.menr.gov.ua/index.php/adaptation.

Директива 2008/98/CC про відходи. URL: https://menr.gov.ua/news/31288.html; Директива № 1999/31/СС про захоронення відходів зі змінами і доповненнями, внесеними Регламентом (СС) № 1882/200326. URL: http://zakon.rada.gov.ua/laws/show/994_925.

${ }^{4}$ Про схвалення Національної стратегії управління відходами в Україні до 2030 року : Розпорядження Кабінету Міністрів України від 08 листопада 2017 р. № 820-p URL: http://zakon5.rada.gov.ua/laws/ show/820-2017-\%D1\%80.
} 
development; the hierarchy of the waste management; integrated information system of waste management; extended producer responsibility; integration into the EU waste market and the European waste management system ${ }^{5}$. To our point of view, the above-mentioned ways of reform are only a part of what should be done in order to approximate the waste management in Ukraine to the European standards. We are confident that in order to make the effective reformation of that function of the public administration of Ukraine possible, in fact, a variety of benchmarks should be accounted as well. This article analyses four of them.

The scientific researches on the administration and legal support of human rights and freedoms; kinds of literature, that account public interests in implementing the functions of public administration; scientific papers on the legal status of public property; the scholars' works on interaction of public administration and institutions of the civil society. The following scholars have dealt with such kind of researching: V.V. Dzharty, N.Yu. Zadiraka, O.O. Kravchuk, Ye.V. Petrov and others. Professional attitude to the subject matter has been mainly defined under the influence of R.S. Melnyk's scientific works.

The following thesis works on certain aspects of waste management in Ukraine had some educative value: T.L. Antonova, O.M. Havriliuk, V.A. Yureskul ${ }^{6}$.

The aim of this article is to evaluate the reformation of the public administration function of the household waste management from four points of view: firstly, to what extend it is oriented at meeting and safeguarding the human rights and freedoms; secondly, whether this function creates necessary conditions to comprehensive accounting of public interest of private persons in this field in full; thirdly, whether this reform encourages private persons as the public administration subjects with delegated power to implementing the function of the national public administration on the household waste management; and finally, does it address the issue of improving the mechanism of household waste management as the public property.In the following paragraphs, each of the above stated issue shall be analysed separately.

\section{The household waste management in Ukraine should be oriented at affirmation and ensuring of human and citizens rights in this direction}

Being the function of the public administration of Ukraine, the household waste management should ease the fulfilling of the main challenges that Ukraine currently faces. The Constitution of Ukraine adheres a specific position in this regard. Accordingly, the p. 2 of the Art. 3 of the Constitution of Ukraine says that human rights and freedoms shall determine the essence and course of

\footnotetext{
${ }^{5}$ Управління відходами. URL: https://menr.gov.ua/timeline/Vidhodi-ta-nebezpechni-rechovini.html.

${ }^{6}$ Дивись у списку використаних джерел.
} 
activities of the State. The State shall be responsible to the individual for its activities. Affirming and ensuring human rights and freedoms shall be the main duty of the State ${ }^{7}$. We think that this provision refers to all subjects of public administration to the same extent. Besides, it serves as a clear benchmark to identify the content and main point of any function of public administration. In other words, there might not be any function of public administration which does not focus at the affirming and ensuring the human rights and freedoms. At this time, the human rights and freedoms should be the corner point in the structure of such function. The goals and tasks should be build around the human rights and freedoms, and their affirmation and ensuring should be in the main stream of public administration of Ukraine. Talking about the household waste management in Ukraine, we should note that wide spectrum of human rights are executed in this area, particularly, the right for environmentally safe and friendly conditions for living and health; the right for being informed about environment condition; the ownership right for household waste as a material resources; the right for entrepreneurship operations related to the household waste; the right for participation in the public hearing, addressing the issues on the location of the household waste handling objects; the right to perform the public monitoring in the field of household waste management etc. In executing its obligations, laid down by the Constitution of Ukraine, it is evident that public administration should direct its efforts at affirmation and ensuring of these rights. Along with that, the National strategy of waste management in Ukraine until the year 2030 insufficiently represents the issues related to the human rights and freedoms. The Strategy considers the human rights in direct way only once, when talking about the measures designed at the necessity to identify the proprietary rights on the household waste. Besides, the aim of this Strategy as well as also the whole process of the waste management in Ukraine, does not cover the issues of the affirmation and ensuring of human rights in this field. Enhancement of the population's standards of living by means of implementing the systematic approach to waste handling at the state and regional level, reducing the volume of waste generation and increasing the volume of waste recycling and reuse, particularly, are in the focus of this Strategy. Obviously, such approach to the definition of the goal of the waste management in Ukraine, does not correlate with the provisions of Constitution of Ukraine as well as does not correspond to those ideas and valuables, underlying the functioning of the European Union. This refers to the respect of democratic principles, human rights and principal freedoms. These ideals are mentioned in the Association Agreement between Ukraine, from one side and the European Union, European society on the atomic energy and their member-states, on the other hand. The

\footnotetext{
${ }^{7}$ Конституція України від 28 червня 1996 p. URL: http://zakon2.rada.gov.ua/laws/show/254к/96-вр.
} 
detailed information about the human rights and fundamental freedoms is contained in the Charter of Paris for a New Europe $(1990)^{8}$. This Charter identifies the requirement on safeguarding the human rights and fundamental freedoms as the first responsibility of the State. Consequently, it is impossible to have the European-kind function of the public administration of household waste management in Ukraine without the priority affirmation and ensuring of the human rights and freedoms.

Within this context, we suggest revising the National strategy of waste management in Ukraine until the year 2030 from the position to what extent its provisions aimed at the affirmation and ensuring of human rights and freedoms, realized in the process of household waste management in Ukraine.

\section{The household waste management should be performed with utmost consideration of public interests of private persons}

To our point of view, any public administration function in Ukraine should be realized with due account for public interests of private persons. That may be concluded, based on the analysis of legal acts of the European Union ${ }^{9}$ and research on the nature of public administration, conducted by European scholars. In this case, the scientific view of M. Benio is very indicative as he attracts the attention that public administration is a set of organizational actions, activity, and measures, performed by different subjects, entities and institutions based on the law and within the forms, identified by the law for achieving the public interest ${ }^{10}$. Therefore, public interest should be considered as a benchmark to direct the activity of public administration and to specify what this administration should approach and what goals and tasks were assigned by the society.

Talking about the household waste management in Ukraine, it should be noted that the public interests of private persons have not been paid sufficient consideration in this field even while drafting the National strategy of waste management in Ukraine until the year 2030. It can be demonstrated in such example: this Strategy suggests to implement "the contaminator shall pay", "the producer's extend responsibility" and "pay for what you are going to get rid of" principles ${ }^{11}$. Implementation of these principles is a balanced and justified step in the conditions of the stable economic situation in the country. As Ukraine has

\footnotetext{
${ }^{8}$ Паризька хартія для нової Свропи 1990 р. URL: http://zakon.rada.gov.ua/laws/show/995_058.

9 Мельник Р.С. Ще раз про сутність та ознаки публічно-правових відносин. Вісник Вищого адміністративного суду Украӥни. 2008. № 4. С. 55-57.

10 Беньо М. Вплив теорії публічної адміністрації на розвиток адміністративного права (приклад Польщі). Законодавство Украӥни. Науково-практичні коментарі. 2006. № 7. С. 8-12.

11 Про схвалення Національної стратегії управління відходами в Україні до 2030 року : Розпорядження Кабінету Міністрів України від 08 листопада 2017 p. № 820-p. URL: http://zakon5.rada.gov.ua/laws/show/820-2017-\%D1\%80.
} 
been facing a deep economic crisis, implementation of the above-said principles would cause the growth of the product unit cost and thus the burden of responsibilities shall be carried by the general public. Perhaps, the employed citizens would cope with that burden but what to do with the socially vulnerable groups of the population?

Therefore, we suggest to update the list of tasks, fixed in the National strategy of waste management in Ukraine until the year 2030 with additional responsibility of the public administration to systematically identify the public interests of the private persons in this field as well as their obligatory accounting in executing the function of public administration on the household waste management in Ukraine.

\section{The private persons should be engaged to an implementation of the public administration function on the household waste management in Ukraine as the subjects of public administration with the delegated powers}

From our point of view, the function of public administration in Ukraine on the household waste management shall contain of the following components: the public management of the household waste administered by the executive authorities; management of the Autonomous Republic of Crimea, administered by its executive authorities; municipal management, executed by the municipal authorities; and management, rendered by private persons, acting as the subjects of public administration with delegated powers. Each of the above said type of management should have its own regulation at the level of the National strategy of waste management in Ukraine until the year 2030. Other words, this Strategy had to define what was required for each type of waste management and what should be done in order for them to become more effective.

That national strategy had to pay specific attention to the development of the institution of the private persons being the subjects of the public administration with delegated powers. Bringing private persons to perform the function of national public administration is quite acceptable and grounded practice for the European Union states. Bringing private persons to household waste management in Ukraine is useful from the point of view that they can execute the majority of tasks, entrusted to the official subjects of public administration (executive power cells, bodies of authorities of the Autonomous Republic of Crimea and municipal authorities). On top of this, such tasks shall be executed by the private persons, acting as the subjects with delegated powers, not at the account of the state, Autonomous Republic of Crimea or municipal budget but shall be funded from their own resources.

It is important to note that the framework the Law of Ukraine "On Waste" does not say anything about the private persons as the subjects of public 
administration with delegated powers. This law of Ukraine does not contain the category of "private person as a subject of public administration with delegated power" or any other analog of this category. Only Art. 23-2 of this law mentions the delegated powers in the light of the monitoring control, performed by the public authorities over the municipal authorities in the context of delegated to them powers ${ }^{12}$. Thereby, the framework the Law of Ukraine "On Waste", being the baseline of the legislation on waste in Ukraine does not bind the private persons with the function of public administration on the household waste management which is from our point of view is a mistake.

Taking into account that the household waste management in Ukraine goes through the reformation stage in this regard it would be interesting to know how much attention is paid to the private persons as subjects of public administration with delegated powers in the National strategy of waste management in Ukraine until the year 2030, which serves as the instrument to approximate the household waste management in Ukraine to the appropriate European standards. Unfortunately, this Strategy does not say anything about the delegating of powers on managing the household waste in Ukraine to private persons. Along with that, it should be taken into consideration that exactly this Strategy serves as a baseline for further legislative works on drafting the Law on waste and secondary resources as well as series of some sectoral Laws, among which there is a Law on household waste. Therefore, it is quite grounded that any further laws, regulating the function of public administration on the household waste management in future, will not designate the private persons as subjects of public administration with delegated powers.

We are confident that the private persons being the subjects of public administration with delegated authorities must be invited to execute the function of public administration of Ukraine on the household waste management. According to the experience of the European Union states, the involvement of these subjects in the household waste management facilitates the use of new technology for collection, transportation, sorting, processing, reutilization and removal of household waste; improves the level of services, provided to the public on the transportation of the household waste; relieves the official subjects of public administration on managing the household waste as the material resources; cuts down the expenses of the budget funds and re-directs them on solving other social issues. In the light of the above, we recommend designing the mechanism of engaging the private persons being the subjects of public administration with the delegated powers to execute the public administration function on household waste management in Ukraine.

\footnotetext{
12 Про відходи : Закон України від 05 березня 1998 р. № 187/98-ВР. Відомості Верховної Ради України. 1998. № 36-37. Ст. 242.
} 
In this regard, it is reasonable to mention that the Directive 2008/98/EC of the European Parliament and of the Council on waste provides that special economic subjects which might be the subjects of public administration with delegated powers, might be engaged to the waste management activity. In this context special economic subjects mean dealers and brokers. In fact, they are private persons being the subjects of economic operations, carrying out the activity, which relates to the household waste, considered as the property. It is strange why National strategy of the household waste management in Ukraine until the year 2030 does not mention anything about those economic subjects. From our point of view, the operations of dealers and brokers should by legally regulated at the level of the legislation of Ukraine on waste. We suggest to amend Art. 1 of the Law of Ukraine "On Waste" (the definition of main terms) with a "dealer" category, defining it as follows: dealer means any natural person or legal entity which buy and then sell the household waste on a regular basis, including those entities which do not possess such waste. Any entity which acquired or sold only once the household waste in the amount that does not exceed fifty tax-free minimum incomes shall not be deemed a dealer.

We also suggest to categorize the concept of "broker" and define it as any private or legal person which, on behalf of others, carries out the activity of use and removal of waste, including such brokers who do not take physical possession of the waste. The specifics of brokers activity in regard to dangerous, radioactive and chemical waste shall be defined by the legislation of Ukraine.

We are confident that introduction of the concepts of "brokers" and "dealers" shall be the necessary condition for reform of household waste management in Ukraine. We suggest to implement these concepts into the legislation of Ukraine with its further obligatory development.

\section{Development of the mechanism of the household waste management as being the public property}

Further development of the institution of the public property in the field of the household waste is covered insufficiently in the National strategy of waste management in Ukraine until the year 2030. Generally speaking, it should be noted that the "property" category is not mentioned at all in this Strategy.

In our opinion, a benchmark in the comprehension of waste category is its statutory definition at the legislative level of Ukraine. Thus, Art.1 of the special Law of Ukraine "On Waste" defines waste as any substance, material and object formed in the process of production or consumption, as well as goods (production), which have completely or partially lost their consumer properties and can't be used at the place of their formation or detection and whose owner 
disposes, intends or must dispose of them by means of utilization or removal ${ }^{13}$. According to the above regulatory definition of the category, waste legislation of Ukraine doesn't consider waste as a property. However, this doesn't mean that waste is not a property. We believe that waste being an object of property right is actually a property, and it can obtain a status either of public or private property depending on a legal regime, which is established towards it. Thus, it is necessary to mark a list of features which will allow separating waste as private property and waste as public property.

We would like to cover a prior issue directly connected with the legal regime of public property, before focusing on the formation of the features of waste as public property. In our opinion, there are two deferent property regimes: a regime of private property and a regime of public property. The former is regulated by the rules of private law. In Ukraine, these sorts of rules are found, for example, in the Civil Code of Ukraine, Family Code of Ukraine ${ }^{14}$ and other statutory acts which govern private relations arising due to property's issue. As for the regime of public property, it is regulated by the rules of public law, in particular, of administrative law of Ukraine. The rules of administrative law, which regulate the legal regime of public property, form the institute within a general administrative law of Ukraine ${ }^{15}$.

Legal regulation of the regime of public property in Ukraine is a quite branched, non-system and has a considerable amount of collisions. We place the Constitution of Ukraine, the Law of Ukraine "On Management of State Property Objects", the Law of Ukraine "On Local Self-Government in Ukraine" and others into legal sources which contain the rules of public law and are devoted to the legal regime of public property. The Law of Ukraine "On Waste" is the special one which defines the status of waste as public property.

Comparing legal regulation of the regime of private and public property in Ukraine, we can mark that legal regulation of public property doesn't have a statutory act which would be a basic, central act in regulating legal regime of public property. Of course, there is the Law of Ukraine "On Management of State Property Objects", but its regulatory influence covers social relations evolving around one of the types of public property, in particular, state property. Legal regulation of the legal regime of republic, municipal property and items of property of the Ukrainian nation is "dispersed" with- in the legislation of Ukraine that complicates clarification of the order of acquisition, change and termination of the

\footnotetext{
13 Про відходи : Закон України від 05 березня 1998 р. № 187/98-ВР. Відомості Верховної Ради Украӥни. 1998. № 36-37. Ст. 242.

14 Цивільний кодекс України від 16 січня 2003 p. URL: http://zakon.rada.gov.ua/laws/show/435-15; Сімейний кодекс України від 10 січня 2002 p. URL: http://zakon.rada.gov.ua/laws/show/2947-14.

15 Мельник Р.С., Мосьондз С.О. Адміністративне право України (у схемах та коментарях) : навчальний посібник / за ред. Р.С. Мельника. Київ : Юрінком Інтер, 2017. С. 50.
} 
legal regime of republic, municipal and public property and items of property of the Ukrainian people. As for private property, a basic regulation of the legal regime is carried out by virtue of a range of codes including the Civil Code of Ukraine, Commercial Code of Ukraine and a number of other regulatory legal acts which define not only the order of acquisition, change and termination of the regime of private property but also give a wide variety of instruments its holder whereby it has the opportunity to determine the subsequent fate of this kind of property. It is referred to civil contracts, estate and others.

It is also important to draw attention to the fact that exercising a legal regulation of the regime of private property by the Civil Code of Ukraine, the legislation of Ukraine misleads one into believing that civil government is a general part for a legal regulation of any type of property. We try to explain this thesis more specifically. Thus, Art. 190 of the Civil Code of Ukrainehas a regulatory definition of the category "property" which is considered as a particular thing, the complex of things as well as property rights or responsibilities. It is also expedient to point out that the Civil Code of Ukraine substituted the Law of Ukraine "On Property" whose rules were devoted not only to private relations in regard to property items but also to public ones. In this context, key issue lies in the fact the Civil Code of Ukraine consolidated a statutory definition of the category "property" as a whole but not the category "private property". This condition has a significant importance because the Civil Code of Ukraine based on private doctrine of property and it is a basic legal source for private law, but not for public. Therefore, it would be worse to consolidate the category "private property" at the regulatory level in Art. 190 of the Civil Code Ukraine. In this respect, it is necessary to turn attention to the lack of category "public property" in the Civil Code of Ukraine. Thus, the category "property" defined in the Civil Code of Ukraine covers both private and public property according to the logic of Ukrainian legislation, and civil regulation is applied not only to private relations but also to public ones in cases which are not directly prohibited by law. We think when solving this issue, it is necessary to take into account the following point: according to the general rule determined in p. 2 Art. 1 of the Civil Code of Ukraine, the civil legislation is not applied to property relations based, in particular, on administrative subordination or other authoritative subordination of one part to another, if another is not established by the law. Thus, juridical basis of the legal regime of public property is public law and, in particular, administrative law. In addition to the above, this doesn't exclude a non-binding application of private law when regulating social relations in respect of public property. If we look at this situation from the point of view of legal regulation of the social relations on waste as public property, then such regulation will have the following form. The 
special Law of Ukraine "On Waste" specifies: waste list which has a status of public property; grounds for acquisition of ownership of such waste; the rights and obligations of the subjects of public administration regarding such property.

From our perspective, that approach is false as the household waste is a property and depending on who owns this waste it may acquire the status of the public or private property. The waste that is owned by the state, the population of the Autonomous Republic of Crimea and the territorial communities shall be regarded as public household waste. In this regard, it is worth to say that the household waste as being the public property is managed by the subjects of public administration of Ukraine. The public authorities, the authorities of the Autonomous Republic of Crimea and municipal authorities shall be qualified as the above-mentioned subjects. This management is the function of that subjects of public administration and stems from the entrusted for them responsibilities to further decide on handling the public and municipal waste as well as the waste of the Autonomous Republic of Crimea.

At the same time, the mechanism of how to manage such waste is only fragmentarily defined in the Law of Ukraine "On Waste". In such, only the parts 3 and 9 of this Law mention that the public waste is managed by the Cabinet of Ministers of Ukraine on behalf of the State. And how to manage the household waste which belongs to the Autonomous Republic of Crimea and that is of municipal communities property? Moreover, the waste which is the property of the Autonomous Republic of Crimea population was not allocated into the separate category. To our deep belief, these questions should be addressed by the National strategy of waste management in Ukraine until the year 2030. In fact, the Strategy does not respond to this question in due scope.

Therefore, we recommend to amend the National strategy of waste management in Ukraine until the year 2030, binding the public administration of Ukraine to develop the mechanism of household waste management, considered as the public property, particularly, the mechanism of management of the public household waste, the waste that belongs to the population of the Autonomous Republic of Crimea and the waste of municipal belonging.

However, the instruments for disposition of such property, for example, by entering into civil contracts aimed at selling resource valuable waste are regulated by the rules of private law, in particular, by the Civil Code of Ukraine.

Continuing with the determination of features list of public property, we should rely on the best practices of researchers because, as we have indicated, the legislation of Ukraine doesn't have a statutory definition for the category "public property". Thus, R.S. Melnyk and V.M. Pyshchyda defines the following features of public property as follows: 1) it is an object of the property of the Ukrainian people, government property and territorial communities' 
property; 2) it may be used, in own discretion, by an unlimited number of members of public relations as many times as they see fit or, at least, to count on such use legally; 3 ) it is a means for the implementation of tasks and functions by the subject of public administration, the creation of conditions for the exercise of rights, freedoms, interests by individuals, as well as satisfaction of social needs and interests; 4) its protection is ensured by the rules of public and private law; 5) objects of public property are protected by law, and the legislation of Ukraine arranges liability for impingement on it etc. ${ }^{16}$.

In our opinion, such a wide features list of public property is a quite natural. In fact, this category combines a large, in terms of volume, list of various types of property that have different physical nature, purpose and legal status, for example, movable or immovable public property, etc. A common thing in these types of property is only a fact that they have the legal regime of public property.

If one compares some features of public property with waste mentioned in scientific literature, we can notice that some of them don't meet the characteristic properties of waste. For example, it is hard to say whether waste serves for the satisfaction of social, cultural, physical and other needs of private persons. However, this does not exclude the fact that this function cannot be performed by other types of public property. Taking into account the abovementioned, it is necessary to distinguish those features of public property that are peculiar to all types of such property and those features that are common to waste as a type of public property.

The general characteristics of public property, which are also peculiar for state, republic and municipal waste, may include as follows: 1)its owner is the state, population of the ARC, territorial communities; 2) the exercise of owner's powers in relation to such kind of property is performed indirectly by the latter, but it is delegated to the subjects of public administration: executive authorities; authorities of the ARC; self-government bodies, subjects of delegated powers; 3 ) origin, change and termination of the status of public property bywaste occurs precisely on the basis of the rules of public law and, in particular, of administrative law of Ukraine. At the same time, it may happen that the rules of private law can be optionally involved in the process of legal regulation of the social relations in regard to waste as public property.

Specific characteristics of waste as public property, in our opinion, are as follows: 1) waste being public property obliges the subjects of publicadministration of Ukraine to manage it. Taking into account this fact, there is a number of public administration functions related to household waste

\footnotetext{
16 Мельник Р.С., Мосьондз С.О. Адміністративне право України (у схемах та коментарях) : навчальний посібник / за ред. Р.С. Мельника. Київ : Юрінком Інтер, 2017. С. 40; Пищида Т.В. Публічне майно як об'єкт публічно-правового спору в адміністративних судах. Науковий вісник Міжнародного гуманітарного університету. Сер.: Юриспруденціія. 2015. № 17. Т. 1. С. 146.
} 
management, industrial waste, waste of construction and repair work, hazardous waste, agricultural production waste, and others; 2) the acquisition of waste ownership as public property does notoriginate from the voluntary actions (desire) of the subjects of public administration in relation to the acquisition of ownership of such property, but from the duty to be guardian to such public property, to determine its further fate which is defined by the legislation of Ukraine; 3) waste is not a means or material basis (base) for the functioning ofthe subjects of public administration. On the contrary, such public property requires additional control over it from public administration, for example, through the creation of landfills for certain types of waste, the construction of waste recycling plants, measures to reduce a negative impact of such public property on public health and natural environment.

Consequently, outlined the list of waste features as public property, on the one hand, we specified more precisely those which are typical for all types of public property, but on the other hand, we named those features that characterize the specifics of waste as a form of public property.

Waste gains the status of public property on the basis and in the manner established by the legislation of Ukraine. At the regulatory level, these grounds are specified in the special Law of Ukraine "On Waste". This Law of Ukraine pays special attention to the grounds for the acquisition of title to state and municipal waste. Thus, according to p. 2 of Art. 9 of the Law of Ukraine "On Waste", a territorial community acquires ownership of waste, which: a) is formed on objects of communal property; b) is in their territory and does not have an owner or its owner is unknown (mismanaged waste). Similar grounds for the acquisition of ownership title are defined for the gain of waste ownership by the state. In accordance with p. 3 Art. 9 of the Law of Ukraine "On Waste", the state holds: a) waste forming on state-owned objects; b) waste which is contained on the territory of Ukraine and does not have an owner or its owner is unknown (mismanaged waste, except municipal waste). At the same time, the above Law of Ukraine mentions nothing about the grounds for the acquisition of the title to Republic's waste that is formed in the territory of the ARC. However, Section III of the Law of Ukraine "On Waste", in particular Arts. 19, 20-1, separately defines a range of powers of the ARC government in waste management sphere. It is an obvious point that these powers are not exercised by the ARC authorities in relation to state or communal waste but in relation to republic's waste, which is formed in the territory of the ARC. Therefore, we believe, it is necessary to rectify this situation and to determine the grounds for the acquisition of ownership of republic waste particularly at the level of the Law of Ukraine "On Waste". It is also should be mentioned, in relation to state waste, the Law of Ukraine "On Waste" makes a significant specification that the Cabinet of Ministers of Ukraine provides 
management of waste, which is a state-owned property, on behalf of the state. The Law of Ukraine "On Management of State Property Objects" is a legal foundation for this management. However, there is an inconsistency between the mentioned Law of Ukraine and the Law of Ukraine "On Waste" in the part of the determination of the grounds for obtainment of ownership of the objects of state management. We studied this collision in the individual paper ${ }^{17}$. Nevertheless, it pays to focus again on the necessity to amend p. 1 Art. 3 of the Law of Ukraine "On Management of State Property Objects" with regard to the specification of the grounds for the acquisition of the right ofstate ownership to a mismanaged property.

\section{CONCLUSIONS}

Bringing the function of public administration on the management of the household waste in Ukraine consistent with the European standards presumes to put in place some measures. Certain of them are indicated in the National strategy of the household waste management in Ukraine until the year of 2030. Provided under this Strategy measures are insufficient to approximate the model of the household waste management in Ukraine to the European analogies.

We estimate that the management of the household waste as the function of public administration in Ukraine shall be subject to obligatory accounting of the human rights and freedoms as well as public interests of the private persons in this field. As such, we suggest to revise the National strategy of the waste management in Ukraine until the year of 2030 from the position that to what extend its provisions aimed at the affirmation and ensuring of human rights and freedoms, realized in the household waste management field in Ukraine. On top of all that this Strategy should provide explicit mechanism of identification and accounting of public interests of the private persons while executing the function of public administration on the household waste management in Ukraine.

The practice of engagement of private persons as the subjects of public administration with the delegated powers is quite useful in all regards, as per our view. Bringing the private persons to execution of the function of the public administration on the household waste management is a common practice for EU states. Recruiting the private persons is beneficial in many respect: it stimulates the usage of the innovative technologies in the process of household waste management; it improves the quality of rendered to the general public services on household collection; it exempts the public administration from the obligation to directly manage the waste as a public property. In the light of the

\footnotetext{
17 Кравченко М.Г. Чи є побутові відходи в Україні майном? Позиція законодавства України та законодавства Європейського Союзу. Журнал східноєвропейського права. 2017. № 43. С. 58-66.
} 
above said we suggest to implement and develop this institution in the field of the household waste management in Ukraine.

Adequate development of the institution of the household waste management as being the public property shall be provided as well. In our view the household waste shall be considered either with the status of public or private property, depending on the applied legal treatment. Sadly to say, but legislation of Ukraine does not provide the appropriate mechanism of the household waste management, being the public property. Due to this reason, we suggest to fill this gap in the legislation of Ukraine and develop the management mechanism of the public and municipal household waste as well as of the waste that belongs to the Autonomous Republic of Crimea.

\section{SUMMARY}

This article is devoted to the analysis of main issues of the household waste management in Ukraine. The author investigates the household waste management as the function of the public administration in Ukraine.The author substantiates the idea that the development of this function of the public administration of Ukraine should be pursued in the following directions. The household waste management in Ukraine should be oriented at affirmation and ensuring of human and citizens' rights in this direction. The household waste management should be performed with utmost consideration of public interests of private persons. The private persons should be engaged to an implementation of the public administration function on the household waste management in Ukraine as the subjects of public administration with the delegated powers.Development of the mechanism of the household waste management as being the public property.Based on the performed analysis, the author suggests to submit the proposal on amending the Ukrainian legislation on waste.

Key words: the public administration function, household waste, human rights and freedoms, public interest, public property, subjects of public administration with delegated authorities.

\section{REFERENCES}

1. Угода про асоціацію між Україною, 3 однієї сторони, та Європейським Союзом, Свропейським співтовариством з атомної енергії і їхніми державами-членами, з іншої сторони : Закон України від 16 вересня 2014 р. Офіиійний вісник Украӥни. 2014. № 75. Ст. 83.

2. Додаток XXX до Угоди про асоціацію між Україною, з однієї сторони, та Європейським Союзом, Європейським Співтовариством 3 атомної енергії і їхніми державами-членами, 3 іншої сторони. URL: http://www.menr.gov.ua/index.php/adaptation. 
3. Директива 2008/98/CC про відходи. URL: https://menr.gov.ua/news/31288.html.

4. Директива № 1999/31/СС про захоронення відходів зі змінами і доповненнями, внесеними Регламентом (СС) № 1882/200326. URL: http://zakon.rada.gov.ua/laws/show/994_925.

5. Про схвалення Національної стратегії управління відходами в Україні до 2030 року : Розпорядження Кабінету Міністрів України від 08 листопада 2017 р. № 820-p URL: http://zakon5.rada.gov.ua/laws/show/8202017-\%D1\%80.

6. Управління відходами. URL: https://menr.gov.ua/timeline/Vidhodi-tanebezpechni-rechovini.html.

7. Джарти В.В. Адміністративно-правові засади управління об'єктами державної власності в Україні : автореф. дис. ... канд. юрид. наук. Запоріжжя. $16 \mathrm{c}$.

8. Задирака Н.Ю. Місце та призначення інституту публічного майна в системі загального адміністративного права. Підприємництво, господарство і право. 2017. № 9. С. 125-128.

9. Кравчук О.О. Адміністративно-правове регулювання управління державною власністю в Україні : дис. ... док. юрид. наук. Київ, 2014. 450 с.

10. Петров Є.В. Адміністративно-господарське право як підгалузь адміністративного права України : дис. ... док. юрид. наук. Харків, 2012. $415 \mathrm{c}$.

11. Мельник Р.С. Система адміністративного права України : дис. ... док. юрид. наук. Харків, 2010. 415 с.

12. Мельник Р.С., Бевзенко В.М. Загальне адміністративне право : навчальний посібник / за заг. ред. Р.С.Мельника. Київ : Ваіте, 2014. 376 с.

13. 100 ответов на 100 вопросов по Общему административному праву : учебное пособие / под ред. Р.С. Мельника. Киев : Юринком Интер, 2017. $240 \mathrm{c}$.

14. Антонова Т.Л. Адміністративно-правове регулювання поводження 3 відходами : автореф. дис. ... канд. юрид. наук. Київ, 2017. 16 с.

15. Гаврилюк О.М. Адміністративно-правове регулювання поводження з побутовими відходами : автореф. дис. ... канд. юрид. наук : Київ, 2017. 16 с.

16. Юрескул В.О. Правове регулювання поводження 3 побутовими відходами : автореф. дис. ... канд. юрид. наук. Київ, 2008. 18 с.

17. Конституція України від 28 червня 1996 p. URL: http://zakon2.rada.gov.ua/laws/show/254к/96-вр.

18. Паризька хартія для нової Європи 1990 p. URL: http://zakon.rada.gov.ua/laws/show/995_058. 
19. Мельник Р.С. Ще раз про сутність та ознаки публічно-правових відносин. Вісник Вищого адміністративного суду України. 2008. № 4. C. 55-64.

20. Беньо М. Вплив теорії публічної адміністрації на розвиток адміністративного права (приклад Польщі). Законодавство Украйни. Науково-практичні коментарі. 2006. № 7. С. 8-12.

21. Про відходи : Закон України від 05 березня 1998 р. № 187/98-ВР. Відомості Верховної Ради України. 1998. № 36-37. Ст. 242.

22. Цивільний кодекс України від 16 січня 2003 p. URL: http://zakon.rada.gov.ua/laws/show/435-15.

23. Сімейний кодекс України від 10 січня 2002 p. URL: http://zakon.rada.gov.ua/laws/show/2947-14.

24. Мельник Р.С., Мосьондз С.О. Адміністративне право України (у схемах та коментарях) : навчальний посібник / за ред. Р.С. Мельника. Київ : Юрінком Інтер, 2017. 344 с.

25. Про управління об'єктами державної власності : Закон України від 21 вересня 2006 p. URL: http://zakon.rada.gov.ua/laws/show/185-16.

26. Про місцеве самоврядування в Україні : Закон України від 21 травня 1997 p. URL: http://zakon5.rada.gov.ua/laws/show/280/97-вp.

27. Господарський кодекс України від 16 січня 2003 p. URL:http://zakon.rada.gov.ua/laws/show/436-15.

28. Про власність : Закон України від 07 лютого 1991 p. URL: http://zakon.rada.gov.ua/laws/show/697-12.

29. Пищида Т.В. Публічне майно як об’єкт публічно-правового спору в адміністративних судах. Науковий вісник Міжнародного гуманітарного університету. Сер.: Юриспрудениія. 2015. № 17. Т. 1. С. 145-148.

30. Кравченко М.Г. Чи $є$ побутові відходи в Україні майном? Позиція законодавства України та законодавства Європейського Союзу. Журнал східноєвропейського права. 2017. № 43. С. 58-66.

\section{Information about author:} Kravchenko M. H., Ph. D., Senior Research Fellow Law Faculty Taras Shevchenko National University of Kyiv 60, Volodymyrska str., Kyiv, Ukraine 